\title{
Towards mass-grave protection guidelines
}

\section{Melanie Klinkner Bournemouth University}

mklinkner@bournemouth.ac.uk

\begin{abstract}
In the aftermath of conflict and gross human rights violations, victims have a right to know what happened to their loved ones. Such a right is compromised if mass graves are not adequately protected to preserve evidence, facilitate identification and repatriation of the dead and enable a full and effective investigation to be conducted. Despite guidelines for investigations of the missing, and legal obligations under international law, it is not expressly clear how these mass graves are best legally protected and by whom. This article asks why, to date, there are no unified mass-grave protection guidelines that could serve as a model for states, authorities or international bodies when faced with gross human rights violations or armed conflicts resulting in mass graves. The paper suggests a practical agenda for working towards a more comprehensive set of legal guidelines to protect mass graves.
\end{abstract}

Key words: mass graves, legal protection, transitional justice, international criminal law, international humanitarian law, international human rights law

\section{Introduction}

Mass graves, often containing hundreds of victims, regularly make news headlines. ${ }^{1}$ In Iraq and Syria alone, more than three thousand victims of Islamic State activities are believed to be buried in such graves. ${ }^{2}$ According to a 2015 United Nations (UN) report, a number of sites reclaimed from so-called Islamic State have been discovered. ${ }^{3}$ Despite limited forensic capacity, the Iraqi government is conducting forensic and judicial investigations into some of the sites in an attempt to preserve evidence for identification and justice efforts. ${ }^{4}$

The rationale for mass-grave protection and investigations is quite clear: through adequate protection and thorough investigations of grave sites, survivor populations are informed about what happened, in an attempt to answer further questions such as why it happened and who may be responsible for the crimes committed. Such evidence from mass graves has been successfully presented in international criminal trials. ${ }^{5}$ While guidelines for investigations of the missing and disappeared 
have been developed by organisations such as the International Committee of the Red Cross (ICRC) ${ }^{6}$ and enforced disappearances themselves have been subject to codification in a convention, ${ }^{7}$ it is not expressly clear how these mass graves are best protected, despite a legal obligation under international humanitarian law that is, the law applicable during armed conflict - to do so. ${ }^{8}$ Human rights principles, too, place an obligation on states to guarantee victims' right to know, right to justice and right to reparation and to provide guarantees of non-repetition. ${ }^{9}$

Although states have an obligation to implement fundamental principles with regard to the dead, missing and survivors, the reality demonstrates that mass graves have often been subject to contamination and disturbance. A Human Rights Watch communication from January 2016 reports that in northern Iraq mass graves are being disturbed, thus potentially compromising their evidential value for future prosecutions. ${ }^{10}$ To make matters worse, in war-torn countries the security situation often does not permit the implementation of investigative efforts. Furthermore, assistance from the international community in protecting and facilitating professional forensic investigations may not always be sufficient or forthcoming. ${ }^{11}$

So, why are there to date no unified mass-grave protection guidelines that could serve as a model for states, international bodies or other appropriate authorities when faced with gross human rights violations or armed conflicts resulting in mass graves? This article seeks to shed light on this question. Producing (and subsequently adhering to) such guidelines, one might reasonably assume, would facilitate and enhance best practice in ensuring that victims of gross human rights violations can be identified and evidence is safeguarded so as to help bring perpetrators to justice. Without explicit guidelines to protect such sites, however, victims' rights to a remedy and reparations may be violated and crucial evidence needed by national and international institutions to pursue investigations and prosecutions of alleged perpetrators may be lost. After an exposition as to why the protection of mass graves should be safeguarded, the article outlines the current legal obligations and guidelines with regard to mass graves. These guidelines fall within legal provisions on missing persons and are formulated, it is argued, at too abstract a level to facilitate specific guidance on mass-grave protection. The article then explores the seemingly paradoxical situation in which, to date, only scant generic guidelines exist even while more focused guidelines are desirable. Finally, the paper identifies a feasible way forward for working towards a more comprehensive set of legal guidelines to protect mass graves. For this discussion the debate is anchored within a transitional justice context to formulate a clear research agenda for the future.

\section{The need to protect mass graves}

After armed conflict and gross human rights violations, an overwhelming need of the families is to know the truth about the fate of their loved ones and, where possible, to receive their human remains as an absolute proof of death to facilitate burial and commemoration rituals. ${ }^{12}$ The need of families to know the truth may 


\section{Melanie Klinkner}

have primacy over wanting justice; the desire for justice may be a secondary consequence of the primary desire to know the truth and receive confirmation of the fate of a family member. ${ }^{13}$

The exact reasons for seeking and ascertaining the truth can vary:

- the return of human remains may be necessary for commemoration practices, funerals and - it is hoped - some sense of closure;

- a death certificate may be required for insurance purposes to safeguard the livelihood of the family;

- information as to the events that led up to the disappearance may explain the absence of an individual, restoring basic human dignity to the disappeared and the family that is left;

- understanding and investigating the fate of those who disappeared may lead to records, answers, accountability and criminal justice efforts at state level;

- documenting the patterns of violence and disappearance may lead to finding missing people who are still alive.

At a societal level, investigating mass graves may contribute to ensuring transparency, ending impunity and protecting human rights. ${ }^{14}$ In a European Court of Human Rights decision, the Court acknowledges the societal relevance of the right to truth, noting its significance in strengthening public confidence in the workings of state institutions and the rule of law more generally. Part of such efforts is to break down 'the wall of silence and the cloak of secrecy'15 that prevented survivors from understanding what had happened to family members and hindered their recovery. ${ }^{16}$

Mass-grave protection is also needed to facilitate evidence collation for criminal investigations and prosecutions, which in turn aim to achieve retributive justice and may assist societies and individuals in the truth-finding process. Particularly during international criminal trials, the preservation and presentation of forensic evidence have been crucial in proving the crime base. Experience from the International Criminal Tribunal for the former Yugoslavia (ICTY) suggests that scientific evidence, especially in relation to mass-grave investigations, has been mostly uncontroversial and generally accepted. ${ }^{17}$ For the International Criminal Court ICC, in line with its complementarity principle and reliance on state cooperation as well as third-party investigations, the protection and preservation of any forensic materials relevant to its mandate are key to successful investigations and prosecutions.

\section{Existing legal obligations and guidelines}

The need for truth and justice is mirrored in international humanitarian law, international human rights law and also through international criminal law, all of which have advanced the recognition of victims' rights in national or international crimes and human rights abuses. ${ }^{18}$ 


\section{International humanitarian law}

Under international humanitarian law, the 1949 Geneva Convention IV stipulates that, in case of death, internees should, where possible, be buried in individual graves that are properly maintained and marked, ${ }^{19}$ and the Additional Protocol I under Article 34(2)(b) demands the protection of gravesites. ${ }^{20}$ Article 8 of the Additional Protocol II provides that ' $[\mathrm{w}]$ henever circumstances permit, and particularly after an engagement, all possible measures shall be taken, without delay [...] to search for the dead, prevent their being despoiled, and decently dispose of them' ${ }^{21}$

Beyond treaty-based law, customary international law, as a source of international law, refers to international obligations placed on states that arise from state practice and opinio juris, that is, the belief that a legal obligation arises. ${ }^{22}$ The Customary International Humanitarian Law (CIHL) study of 2006, a major international study into current state practice in international humanitarian law in order to identify customary law in this area, ${ }^{23}$ sets out a comprehensive set of provisions on the dead, the gravesites and missing persons. ${ }^{24}$ Moreover, several of these identified provisions apply during international and internal armed conflict. ${ }^{25}$ This is crucial, as many of today's conflicts may not qualify as international armed conflict but, rather, as non-international or internal armed conflict, often with non-state actors as well as state actors engaged in violence that may result in human rights violations. Identifying customary international law on the subject is important in so far as the norms characterised as customary bind states that are not parties to instruments codifying the right or obligation in question. ${ }^{26}$ In other words, the provisions are applicable and binding to all states, regardless of their treaty obligations.

In addition to the requirement to search for, collect and evacuate the dead, applicable during both international and internal armed conflict, as identified by the CIHL through its study of treaty law, state practice (as evidenced in military manuals, for example), domestic laws and case law, are the following provisions: (1) the need to 'take all possible measures to prevent the dead from being despoiled', with the mutilation of dead bodies being categorically prohibited; ${ }^{27}(2)$ respectful disposal of dead bodies, including respect for and maintenance of the graves; ${ }^{28}$ (3) for the purposes of identification, parties' obligation to record information before the burial and mark the grave location. ${ }^{29}$ It is, however, an obligation of means to identify the dead, with parties being required to make their best efforts to ensure identification. This should be achieved through collection of one half of the identity disk, autopsies and their records, issuing of death certification, recording of the burial place and burial in individual graves, which have to be marked. Burial in collective graves without prior identification is not permissible unless unavoidable circumstances, such as sanitary and health purposes, require the use of such graves. ${ }^{30}$ After burial, forensic exhumations and investigations, including DNA tests, may facilitate identification. The return of human remains upon request by a party or the next of kin, ${ }^{31}$ as a sign of respect for family life and regard for survivor rights, is also viewed to be applicable during non-international armed conflict.

On the subject of the missing, the following rule is deemed to form part of 


\section{Melanie Klinkner}

customary international humanitarian law for both international and internal armed conflict: 'Each party to the conflict must take all feasible measures to account for persons missing as a result of armed conflict and must provide their family members with any information it has on their fate. ${ }^{32}$ Support for this position can also be found in military manuals and national laws on the missing. ${ }^{33}$ However, the obligation to account for missing persons, it ought to be stressed again, is an obligation of means, with parties to the conflict obliged to use their best effort to search and facilitate the search for persons missing as a result of armed conflict. This can include excavation of human remains.

\section{International human rights law}

The need for full information on behalf of victims and survivors of gross human rights is mirrored in international human rights law and has been acknowledged by human rights courts. ${ }^{34}$ While initially linked to enforced disappearance, ${ }^{35}$ the right to truth has been broadened into other areas of gross human rights violations, including torture and extrajudicial killings, ${ }^{36}$ and is significant for the discussion on victims' rights pertaining to mass graves, as it offers a legal avenue for victims and survivors to find out what happened to their family member. Express codification of the right to truth in convention law can be found in Article 24(4) of the International Convention for the Protection of All Persons from Enforced Disappearance, which grants each victim 'the right to know the truth regarding the circumstances of the enforced disappearance, the progress and results of the investigation and the fate of the disappeared person. Each State Party shall take appropriate measures in this regard. ${ }^{37}$

The UN's 2006 Basic Principles ${ }^{38}$ are also important to the discussion. They attempt to bring together the legal positions on remedies for victims of gross violations in both fields of international law, given that there is significant overlap. In particular, the authors had in mind gross violations that would constitute international crimes under the Rome Statute. ${ }^{39}$ Principle 24 covers the following obligation:

[V]ictims and their representatives should be entitled to seek and obtain information on the causes leading to their victimization and on the causes and conditions pertaining to the gross violations of international human rights law and serious violations of international humanitarian law and to learn the truth in regard to these violations. ${ }^{40}$

Under this provision, the state is obliged to develop ways to fulfil the rights of individuals seeking information on the reasons for and circumstances of the abuse suffered - this includes investigations of gross human rights abuses resulting in mass graves. The unanimous adoption of the Basic Principles by the UN General Assembly signifies authoritative backing.

The right to truth defines an entitlement to seek and obtain information relating to the reasons for and circumstances of the victimisation. A necessary presupposition is the existence of gross/massive or systematic human rights abuses. ${ }^{41}$ Therefore, an obligation is placed on the state (and to some extent on the inter- 
national community) following on from post-conflict situations and systematic human rights abuses. As such, the right to truth is part of a mix of state obligations including the right to justice, the right to reparation and also the obligation to remove from office those who participated in the crimes. ${ }^{42}$ At its core, positive and affirmative action is required by the state to undertake continued and systematic efforts to investigate the abuses and to gather the evidence in an attempt to answer questions about what happened, why it happened, to identify those responsible, directly and indirectly, ${ }^{43}$ and understand the patterns of abuse.

\section{International criminal law}

Prior to discussing international criminal legal provisions with regard to mass graves and the potential causes relating to mass graves, it is worth distinguishing the following types of mass graves: not all mass graves are necessarily unlawful containing unlawfully killed humans - the Haitian earthquake victims of 2010 are a stark reminder of this grim reality. ${ }^{44}$ The UN Commission of Experts' report for Bosnia-Herzegovina and Croatia distinguished four types of mass graves: (1) bodies were subject to mass killing but buried properly; (2) human remains are those of civilian casualties and soldiers killed in combat but the burial was improper; (3) victims of mass killings were buried improperly; (4) the circumstances surrounding the death and the burial method were improper. ${ }^{45}$

Under international criminal law, enforced disappearance and extrajudicial killings which may lead to the existence of clandestine graves are unlawful and, when perpetrated as part of a widespread or systematic attack directed against civilians, may constitute a crime against humanity. ${ }^{46}$ Similarly, intentionally directing attacks at a civilian population or wilful killing within an armed conflict may be a war crime. ${ }^{47}$ In addition, and consistent with most religious and cultural practices, international humanitarian law prohibits the despoliation and mutilation of the dead. 'Robbing the dead', it was held at the US Military Tribunal in Pohl et al., 'even without the added offense of killing, is and always will be a crime." ${ }^{48}$ This too is reflected in the Rome Statute under Articles 8(2)(b)xxi and 8(2)(c)(ii) criminalising 'outrages against personal dignity, in particular humiliating and degrading treatment'. ${ }^{99}$ According to the International Criminal Court's Elements of Crimes this includes dead persons. ${ }^{50}$ Mutilating human remains and despoiling graves can have adverse effects on investigation and identification efforts, impeding justice efforts and exacerbating the suffering of survivors. A missing person who is in fact dead may continue to be classified as missing due to the lack of identification of human remains. Jurisprudence from the ICTY has reflected on this point when dealing with the many secondary graves created in an attempt to conceal the initial crimes. $^{51}$

\section{Guidelines on 'missing persons'}

The wider framework of missing persons in the context of armed conflict is naturally relevant to mass graves by virtue of missing persons often being the result of armed conflict, enforced disappearances or extrajudicial killings. Following the Balkan wars in the 1990 s, unidentified victims from mass graves remain. ${ }^{52}$ 


\section{Melanie Klinkner}

In the International Court of Justice's 2015 'Serbia-Croatia' judgment, the Court expressly refers to the continuing issue of missing persons in relation to the crime of genocide, acknowledging that 'in the present case, the relatives of individuals who disappeared during the events that took place on the territory of Croatia between 1991 and 1995 suffer psychological distress as a result of the continuing uncertainty which they face. ${ }^{53}$

The ICRC is a driving force regarding the needs and rights of missing persons and in 2003 formulated recommendations for drafting national legislation with regard to missing persons which reflect international humanitarian law. The document outlines parameters for the treatment of the dead and their identification, suggesting that domestic laws and regulations need to be implemented so as to ensure that the identity of human remains and the cause of death are ascertained with due diligence and by the relevant authority. ${ }^{54}$ Similarly, it suggests that exhumations need to take place within a legal framework and with the relevant authorisation granted. ${ }^{55}$ In other words, in this document the ICRC provides the wider international legal framework which domestic legislation should reflect.

In 2009, the ICRC drafted a more comprehensive 'Guiding Principles/Model Law on the Missing'. Part V of the document outlines legislative principles relating to the search for, recovery and treatment of the dead, reiterating key elements from the earlier 2003 'Recommendations' and is most relevant for a discussion on mass graves. The newer 'Guiding Principles' also offer commentary, discussing and contextualising the key proposed provisions. Article 19 spells out the obligation to search for and recover the dead: 'Once the fate of a missing person has been determined to be death, all available means must be undertaken to ensure recovery of the body and any personal effects. ${ }^{56}$ This chimes with international humanitarian law requirements discussed above. Similarly, Article 21 on the treatment of the human remains places an onus on the competent authorities to identify human remains using qualified officials, through exhumations if needed, so that the cause of death can be established with due diligence. ${ }^{57}$ The Article also provides that exhumations during international armed conflict are permitted only for either identification purposes and the of return human remains and personal effects to the home country (should this have been requested), ${ }^{58}$ or if public necessity, such as health and safety reasons, demands the exhumation. ${ }^{59}$ Article 21 (4) stipulates that '[h] uman remains and personal effects shall be returned to the families' ${ }^{60}$ The provisions also cover the required burial, exhumation and commemorative practice $^{61}$ and how to treat unidentified human remains, stipulating that records are kept, identification efforts continue and the family be kept informed. ${ }^{62}$

What the 'Guiding Principles' do not offer - and do not claim to offer - is a model law or a template to implement legislation for mass-grave protection and the necessary specific requirements. However, in the commentary useful information can be discerned for mass-grave protective and investigative measures. It clearly suggests that a domestic legal framework is needed to facilitate effective, authoritative investigations both for state-agent perpetrated crimes and for the dead resulting from international and non-international armed conflict, placing a duty on these authorities to provide the necessary information to families and to 
issue death certificates. Similarly, this legislative framework is needed to ensure that evidence of criminality is forwarded to the competent authorities. Moreover, and in line with the domestic law, qualified professional forensic specialists should be employed to carry out and/or oversee the handling of human remains. Cremation, the guidelines suggest, should be avoided and burial, after the relevant examinations, should be, where possible, in individual marked graves. ${ }^{63}$ Furthermore, while criminal liability can be incurred for illegal arrest, detention, extrajudicial killings and enforced disappearances (crimes which typically cause people to go missing), refusal or delays to provide relevant information on the missing can also constitute a criminal act, as would the intentional mutilation, despoliation and desecration of the dead. The latter is crucial for the protection of graves, as desecration would be a crime in itself and cause significant impediments to investigative work.

While there is a strong identification of the need for a legal, regulatory framework, the ICRC 'Guiding Principles' do not venture into how this legal framework ought to be set up. However, they do stipulate that the responsible authority ought to uphold an ethical code of conduct for such investigations and identification efforts. ${ }^{64}$ In addition, they suggest that in order to ensure a chain of responsibility, authority, accountability and, presumably, custody of evidence, one authority should be responsible for the protection and recovery of human remains. ${ }^{65}$ The issue in conflict and immediate post-conflict situations, however, is that the rule of law, and with it the authorities, may have collapsed, leaving a legal and institutional void. Nonetheless, the commentary insists that Standard Operating Procedures for the armed forces, armed groups and civilian service are needed to, firstly, guide the search for, collection and identification of the dead without distinction; secondly, facilitate the exhumation, collection, transportation, temporary storage, burial and repatriation of human remains; and thirdly, offer training on how to identify and treat human remains. ${ }^{66}$

The 2010 UN Human Rights Council Progress report on the issue of missing persons concurs with the ICRC's 'Guiding Principles', reiterating that the onus is on national legislation to provide the necessary framework to deal with the dead and human remains. ${ }^{67}$ It suggests that the identification, mapping and preservation of a burial is paramount. The report also acknowledges that the passage of time adversely affects the possibilities to account for the missing and that informationseeking efforts need to be extended to multiple sources and that these sources may need to be protected through guarantees of anonymity. ${ }^{68}$ And it urges for criminal sanctions in cases where gravesites are desecrated. ${ }^{69}$ In terms of identification, methods should rely on more than just one technique (i.e. if possible not solely on DNA).${ }^{70}$ As in the ICRC's 'Guiding Principles', there is a clear general message that exhumations should be performed only with the relevant authorisation and in line with the local law, which should adhere to some ethical principles, although this remains at an abstract level, leaving the onus and the detail to be determined locally. Furthermore, there is no mention of how the burial sites are to be protected, despite this being identified as a key step in facilitating identification and evidence collection.

The International Commission on Missing Persons (ICMP), which has 


\section{Melanie Klinkner}

specialised in addressing the issue of missing persons and offers assistance to states, also acknowledges that 'no universal standards for the investigation of missing persons cases exist yet', ${ }^{71}$ although guidance, as discussed above, is available. This includes guidance for specific aspects of an investigation, such as genetics, technologies, human genetic data, its storage and processing. ${ }^{72}$

\section{From the abstract to the more concrete}

Countries have voiced demands for assistance with mass-grave protection and the more general issue of missing persons. ${ }^{73}$ Countries have also identified the need to develop legal instruments to deal with the missing and mass graves. Indianadministered Kashmir urged for protection of mass graves in order to avoid their desecration and destruction. ${ }^{74}$ Bosnia-Herzegovina and the Republic of Kosovo have legal provisions for the missing ${ }^{75}$ and in 2014 the presidents of some Balkan states pledged their commitment to the resolution of the missing persons issue in line with human rights principles and the rule of law. ${ }^{76}$ Afghanistan has criminalised disturbances to graves, and in 2013 Physicians for Human Rights (PHR) issued a report offering a human-identification needs assessment. ${ }^{77}$ Both the ICMP and PHR have been involved in assisting Libya with the location, recovery and identification of missing persons.$^{78}$ Some of their findings are alarming, suggesting that Libyan efforts fall well short of international norms and standards, indicating insufficient provision for serious investigations, unsatisfactory family and stakeholder consultation and discriminatory practice towards families of the missing, with families of martyrs receiving favourable treatment. ${ }^{79}$ As discussed below, Iraq has enacted a specific law on the protection of mass graves in order to regulate the investigation process and ensure the preservation of evidence so as to facilitate victim as well as perpetrator identification.

This brief list gives an indication of the widespread, multifaceted and complicated nature of mass graves, where actors such as the UN, PHR and ICMP have played a vital role. A common thread is the need for clarity on processes and assistance with implementation.

\section{Domestic efforts: Iraq}

To examine whether existing guidance has been followed and general principles have been filled with concrete provisions, the Iraqi law on the protection of mass graves and its legacy are analysed. The Iraqi law makes an excellent example, as this is the only law listed on the ICMP's website concerned solely with mass graves. ${ }^{80}$ Furthermore, much international attention and involvement has been focused on Iraq and its mass graves. ${ }^{81}$

In 2006 Iraq's Ministry of Human Rights issued a 'Law on Protection of Mass Graves' ${ }^{82}$ The law formulates four aims: (1) to protect the graves from unauthorised disturbance; (2) to provide legal regulations for mass-grave investigations and their legal consequences; (3) to preserve and protect evidence to identify victims; and (4) to identify perpetrators and collect evidence to prove responsibility. The verbatim formulation of these aims (which are paraphrased here) in the transla- 
tion available through ICMP is somewhat curious, not least as the identification of the perpetrator seems to precede the collection of evidence, nor is it explicitly clear what is meant by 'legal consequences'. Notwithstanding these issues, which may be due to translation, the law identifies a responsible authority, the Ministry of Human Rights, to take charge of the mass-grave documentation and investigation process. ${ }^{83}$ It offers a definition of what is classified as a mass grave (land or location containing the mortal remains of more than one victim) and suggests a stringent time-line for the various actions prescribed within the law (although some of those time stipulations appear quite ambitious). For example, the law places a duty on all persons who know about a mass grave's existence on their land to report it to the authorities within thirty days of the law's enactment.

Implementation, and presumably enforcement, of the law is facilitated through the establishment of a regional commission which is led by a ministry representative and comprising of a judge, a member of the Public Prosecutor Department, a police officer, a forensic expert and a representative of the municipal council. The key functions of the commission are to facilitate and oversee the mass-grave investigation and recording with a view to identifying the victims; to repatriate human remains to the families and rebury the victims in line with their customs at the expense of the state; to issue an identification document for all human remains; and, lastly, '(d) [i]ssue decisions needed for the implementation of its assignments as prescribed by this article and lift them to the Ministry for it to start legal procedures' ${ }^{84}$ This latter provision might mean that relevant evidence for prosecutorial and other recording purposes is passed on to the Human Rights Ministry. There are provisions for the issuing of an identification document (which presumably equates to a death certificate), ${ }^{85}$ the return of personal belongings and the sharing of information with the Missing Persons Office.

There is a provision for a mass-grave guard to protect the grave ${ }^{86}$ and penalties are stipulated for disturbing graves, interfering with investigations or otherwise breaching the law. ${ }^{87}$ Absent from this law, and somewhat inconsistent with the principles suggested by the ICRC, is the lack of reference to any ethical requirements or to Standard Operating Procedures. But Article 17 provides that to implement the goals of this Law, and to document the procedures undertaken in accordance with this Law and its results on national and international levels, the Ministry shall request assistance of relevant authorities as well as local and international human rights organizations', which could be interpreted to mean that organisations with the necessary forensic and medico-legal capacity for investigations of this nature, including the necessary ante- and post-mortem data collection, would be consulted or asked to provide assistance. In turn, these assisting organisations would operate with strict protocols and standard operating procedures. Similarly, Article 17 suggests that '[i]nternational agreements and conventions ratified by Iraq shall be applied to any cases that the Law failed to define in specific terms', thus making reference to a wider international framework that may be applicable to this law.

Yet, as the 2015 UN report states, there is still much to be done with regard to mass graves, and it urges the Iraqi government to: 


\section{Melanie Klinkner}

[e]nsure the protection of mass graves along with appropriate care and measures to excavate such sites and to exhume and identify the remains of the dead, and to preserve evidence of crimes committed, including any that may lead to the identification of perpetrators. Conduct independent, public coronial inquiries into each mass grave, to identify the victims, collect evidence of wrongdoing, and to fully investigate and determine the circumstances that led to the deaths of the individuals concerned and ensure that members of victims and missing persons [sic] [families] should be provided with all available information and adequate and timely financial, material, and other assistance. ${ }^{88}$

The report recommends that the international community should provide assistance for the identification, excavation and investigation of mass graves. While in principle a domestic law which suggests some compliance with ICRC standards may be in place, the effect of this law is not all-encompassing some nine years after its enactment. With this, the question of why we do not have specific guidelines to protect and safeguard mass graves takes another twist: why, if there is a specific law, is there still room for improvement?

\section{The paradox: a universalist need but no one way}

In post-conflict societies it may not be clear who is (or who can be) legally in charge of mass-grave sites or the protection of crime scenes in general. This is why producing a blue-print for mass-grave protection, in theory, sounds like a compelling project, especially as mass-grave exhumations fulfil many important functions. ${ }^{89}$ However, as transitional justice tends to be a reaction to exceptional circumstances, it becomes very difficult to generalise guidelines and create templates for future transitional justice provisions. ${ }^{90}$ If scholars of transitional justice have learnt one thing, it is that there is no 'justice à la carte', ${ }^{91}$ and no blue-print that can be easily accessed without bottom-up adaptation in post-conflict situations. And yet, in conflict and post-conflict situations, where the rule of law has often broken down, the need for protection is perhaps more important than at any other time. A mass-grave protection guideline would provide states, state actors, armed groups, occupying forces, civil society and specialist agencies with clear guidance as to how mass graves ought to be treated: from the time of their discovery, to their reporting, protection, excavation and medico-legal investigation, psycho-social family liaison, identification and repatriation of remains and potential prosecutions.

There is an underlying consensus that mass-grave protection and investigation (to varying degrees ${ }^{92}$ ) is desirable, although the exact parameters for protection and investigation are contested. Conundrums are many: cultural and religious sensitivities need to be respected, legal traditions and systems may need to be integrated within an international framework, dedicated and functioning authorities are essential for the operationalisation and overseeing of processes, agreement on investigative and scientific processes is required, security must be safeguarded by an appropriate authority and so on. In essence, there are two crucial issues: 
1 How to retain core principles that would facilitate the respectful and acceptable protection and investigation of mass graves and yet remain adaptable to the specific context at hand.

While the Iraqi law may to some degree have mastered the first issue, it appears that it is stumbling at the second, hindered by the many other challenges Iraq is facing, not least from so-called Islamic State. The second issue therefore is:

2 How to integrate the variety of stakeholders needed to implement mass-grave protection and investigation.

Iraq's challenges, however, do not present an argument not to pursue the overcoming of the first issue. In fact, it would indicate the opposite: the clearer the guidelines, the more explicit become the requirements placed on stakeholders. Having guidelines turns the initial problem of balancing aims and stakeholder requirements into an operational one. The first issue is far from unique to the world of mass graves, but permeates much of transitional justice literature. Retaining core principles while adapting to contexts is what transitional justice efforts are about. And it is through the lens of transitional justice that a way forward might be found.

\section{Working towards greater specificity: the way forward}

Transitional justice is defined as encompassing 'the full range of processes and mechanisms associated with a society's attempt to come to terms with a legacy of large-scale past abuses, in order to ensure accountability, serve justice and achieve reconciliation'. ${ }^{93}$ These mechanisms can be judicial or non-judicial, ${ }^{94}$ designed to offer practical strategies to address the complex legacies of gross human rights abuses while being responsive to victims. The term 'transitional justice' itself originates from the 1990s and is perhaps better described as 'justice during transition', with transition meaning a period of often complex political changes. ${ }^{95}$ Transitional justice came into being through human rights activists, lawyers, legal and political scholars, policy makers and journalists' interaction, facilitated by donors, to advance human rights and also transitions to democracy. ${ }^{96} \mathrm{~A}$ key premise was to compare experiences from across the world and differing, varying transitions and conflicts rather than to identify an ideal-type of transition. ${ }^{97}$ And it is this comparative approach that sounds promising.

Through this comparative, multidisciplinary approach much can be learnt and brought together in a meaningful way that allows for the expression of more specific core principles tailored to mass graves, while leaving some room for flexibility. The ICRC's 'Guiding Principles', through its Articles (expressing the core principles) and its commentary (discussing the rationale for specific provisions and their interpretation), provides just this, albeit for the much broader subject of missing persons generally. Similarly, the 'Belfast Guidelines on Amnesty and Accountability' ${ }^{98}$ advance our understanding on 'accountable amnesties' and what they would entail, following the same model of offering guidelines and an accompanying commentary. Such guidelines are not, it should be stressed, legally binding 


\section{Melanie Klinkner}

per se, unless they reflect customary international law. However, international organisations are increasingly influential in the process of law making, particularly on customary international law ${ }^{99}$ and in the development of 'soft law', which can be a first step towards the development of 'hard law' that is binding. ICMP, which now has been recognised as an international organisation, could take the lead on such a project, specifically as it fits well with its recommendations contained in the 2013 conference report on the missing. ${ }^{100}$ The report suggests that there is a need to better define and address legal responsibilities and safeguarding standards ${ }^{101}$ and that ' $[t]$ he responsibility of States on missing persons issues should be advanced through appropriate instruments' ${ }^{102}$ As outlined above, states have a vested interest in receiving assistance and guidance, which is a positive sign towards subsequent adherence.

The method to achieve greater clarity and specificity has been tried and tested too, and consists of a structured, well-planned combination and iteration of stakeholder consultation and round-table discussion. To advance our understanding of the intricate issues associated with mass-grave protection, stakeholders from the military, forensic sciences, criminal investigations, legal profession, nongovernmental organisations and local survivor groups need to come together to explore them in a structured and focused manner. Such a cross-disciplinary approach involving researchers, practitioners and those most affected by conflict is essential to ensure that any future guidelines take into account the different and possibly conflicting needs and sensitivities of survivors vis-à-vis the demands of criminal justice and scientifically robust practices.

As a first step in the process, draft guidelines created following analysis of existing literature, policy and procedure ought to form the basis for an initial consultation with stakeholders and invitation to comment on the draft. A refined version of the draft would then form the basis for the first round-table discussion to debate and advance the guidelines. Given the variety of issues associated with mass graves, establishing sub-panels to discuss and progress particular aspects such as psychosocial, cultural and religious sensitivities; investigative and scientific processes; applicable legal framework; securitisation and operationalisation should be considered. Based on the outcomes of the first round-table discussions, the guidelines would need to be refined, before invitation of further comments and the convening of another round-table discussion aimed at finalising the guidelines.

Working with a cross-disciplinary expert and stakeholder group that reviews and refines draft guidelines in an iterative process would help to capture a range of views on (1) what issues should be addressed in the mass-grave guidelines, from the basic rights of families in respect of mass graves, to adequate protection of graves from disturbances, to regulating forensic investigations; and (2) what approach the guidelines should take in response to a range of issues and conflicting interests. Furthermore, this method would ensure plurality, legitimacy, validity and wide acceptance among key stakeholders, maximising the chances of implementing mass-grave protection efforts. 


\section{Conclusion}

This article has traced the rationale for mass-grave protection, outlined the international legal obligations relating to mass graves and their survivors and discussed the general principles that can be discerned from guidelines on the missing. It has considered domestic needs and a domestic effort of legal provision to protect mass graves. With compelling evidence suggesting that mass-grave protection and investigations are of the upmost importance, the question arises as to why no specific mass-grave protection guidelines exist. The answer to this question lies in the difficulties of juggling multiple stakeholders, core values and the specificities of context. This in itself is nothing new but, rather, an issue perpetuated within the wider transitional justice realm.

Not despite the difficulties to provide guidance but, rather, because it is so challenging, it is important to get clarity on as many of the contested issues as possible. A feasible way forward would be to bring multiple actors with a vested interest in mass graves and their protection together. The idea is that they can learn from one another, in a structured and focused manner, to build up an experience base. This in turn would ensure that the universal elements could be discerned, while exploring avenues for flexibility with regard to mass-grave protection. The same crossdisciplinary expert and stakeholder group would review and refine draft guidelines in an iterative process until a consensus and final guideline could be agreed. To be clear: to believe that an agreed mass-grave protection guideline would be a silver bullet is highly naïve, but if it became a tool to enhance the chances of identifying victims of gross human rights violations and of safeguarding evidence to help bring perpetrators to justice, surely a persuasive argument to pursue the endeavour would have been made.

\section{Notes}

1 International Commission on Missing Persons, 'Yazidi Women in Mass Graves', http://www.icmp.int/news/yazidi-women-in-mass-graves/ and 'Where are the Missing?', http://www.icmp.int/the-missing/where-are-the-missing/ (all internet sources accessed in February 2016).

2 J. Moore, 'ISIS Mass Grave Death Toll in Iraq and Syria Surpasses 3,000', Newsweek, 4 August 2015, http://europe.newsweek.com/ isis-mass-grave-death-toll-iraq-and-syria-surpasses-3000-320590.

3 Office of the United Nations High Commissioner for Human Rights and United Nations Assistance Mission for Iraq, 'Report on the Protection of Civilians in the Armed Conflict in Iraq: 11 December 2014 - 30 April', http://www.ohchr. org/Documents/Countries/IQ/UNAMI_OHCHR_4th_POCReport-11Dec201430April2015.pdf, hereinafter UN Report on the Protection of Civilians in the Armed Conflict in Iraq.

4 Ibid., p. 33.

5 For example, Prosecutor v Krstić, Judgment, Case No IT-98-33-T, 2 August 2001 
and Prosecutor v Karadžić, Public redacted version of Judgment issued on 25 March 2016, Case No IT-95-5/18-T, 25 March 2016.

6 International Committee of the Red Cross (ICRC), 'Guiding Principles/Model Law on the Missing' (2009), https://www.icrc.org/en/document/guidingprinciples-model-law-missing-model-law and 'ICRC Report: The Missing and their Families. Summary of the Conclusions arising from the Events held prior to the International Conference of Governmental and Non-Governmental Experts (19-21 February 2003)' (2003), https://www.icrc.org/eng/assets/files/other/ icrc_themissing_012003_en_10.pdf, hereinafter ICRC Report: The Missing and their Families.

7 International Convention for the Protection of All Persons from Enforced Disappearance, adopted 12 January 2007, entered into force 23 December 2010, UN Doc A/RES/61/177, Article 24(2).

8 A. Petrig, 'The War Dead and Their Gravesites', International Review of the Red Cross, 91 (2009), 341-69.

9 UN Commission on Human Rights, Report of the Independent Expert to update the Set of Principles to Combat Impunity, 18 February 2005, UN Doc. E/ CN.4/2005/102.

10 Human Rights Watch, 'Iraq: Protect Mass Graves', https://www.hrw.org/ news/2016/01/30/iraq-protect-mass-graves.

11 UN Report on the Protection of Civilians in the Armed Conflict in Iraq, p. 36.

12 M. Doretti and L. Fondebrider, 'Truth, Justice, Reparation and Reconciliation, a Long Way in Third World Countries', in V. Buchli and G. Lucas (eds), Archaeologies of the Contemporary Past (Abingdon, Routledge, 2001), 138-44; T. Robins, 'Towards Victim-Centred Transitional Justice: Understanding the Needs of Families of the Disappeared in Postconflict Nepal', International Journal of Transitional Justice, 5:1 (2011), 75-98.

13 Robins, 'Towards Victim-Centred Transitional Justice'.

14 See, for example, United Nations Human Rights Council, Resolution 9/11, UN Doc. A/HRC/L.12, para. 1.

15 El-Masri v. The former Yugoslav Republic of Macedonia, ECtHR, Application no. 39630/09, 12 December 2012, Joint concurring opinion, para 6.

16 Ibid.

17 M. Klinkner, 'Scientific Evidence in International Criminal Trials', in D. Weisburd, (ed.), Encyclopedia of Criminology and Criminal Justice (New York, Springer, 2013).

18 C. Bassiouni, 'International Recognition of Victims' Rights', Human Rights Law Review, 6:2 (2006), 203-79.

19 Geneva Convention (IV) relative to the Protection of Civilian Persons in Time of War (adopted 12 August 1949), 75 UNTS 288, Article 130.

20 Protocol Additional to the Geneva Conventions of 12 August 1949, and relating to the Protection of Victims of International Armed Conflicts, 8 June 1977, 1125 UNTS 3.

21 Protocol Additional to the Geneva Conventions of 12 August 1949, and relating 
to the Protection of Victims of Non-International Armed Conflicts, 8 June 1977, 1125 UNTS 609, Article 8.

22 United Nations, Statute of the International Court of Justice, 18 April 1946, Article 38(3).

23 J.-M. Henckaerts and L. Doswald-Beck, Customary International Humanitarian Law, Volume I: Rules (Geneva, Cambridge University Press, 2006), hereinafter CIHL Study.

24 Petrig, 'The War Dead and Their Gravesites', 368.

25 C. Pilloud and others, Commentary on the Additional Protocols of 8 June 1977 to the Geneva Conventions of 12 August 1949 (Geneva, Martinus Nijhoff, 1987).

26 T. Meron, The Humanization of International Law (The Hague, Martinus Nijhoff, 2006), p. 357.

27 CIHL Study, Rule 113. See, for example, First Geneva Convention, Article 15(1); Second Geneva Convention, Article 18(1); and Fourth Geneva Convention, Article 16(2). This was also established in Pohl et al., US Military Tribunal in Nuremberg, Judgment, 3 November 1947.

28 CIHL Study, Rule 115. Codification can be found, for example, in the First Geneva Convention, Article 17; Second Geneva Convention, Article 20; Third Geneva Convention, Article 120; and Fourth Geneva Convention, Article 130. See also, Evacuation of bodies in Jenin, Decision of the Supreme Court Sitting as a High Court of Justice, Israel, 14 April 2002.

29 CIHL Study, Rule 116. Codification can be found, for example, in the First Geneva Convention, Articles 16-17; Second Geneva Convention, Articles 19-20; Third Geneva Convention, Articles 120-122; and Fourth Geneva Convention, Articles 136-139.

30 CIHL Study, Rule 115.

31 CIHL Study, Rule 114. Although Petrig, 'The War Dead and Their Gravesites', notes that there is state practice to the contrary: in Russia federal law forbids the return of bodies of terrorists.

32 CIHL Study, Rule 114.

33 UN Commission on Human Rights, Study on the Right to the Truth, Report of the Office of the United Nations High Commissioner for Human Rights, 8 February 2006, E/CN.4/2006/91, footnotes 8 and 21.

34 Case 10.488, Ignacio Ellacuría et al v. El Salvador Report No. 136/99 (1999) and El-Masri v. The former Yugoslav Republic of Macedonia, Application No. 39630/09, Judgment, 13 December 2012.

35 First Report of the UN Working Group on Enforced or Involuntary Disappearances, UN Doc. E/CN.4/1435, 26 January 1981, para 81. See also Organization of American States (OAS), Inter-American Convention on Forced Disappearance of Persons, 9 June 1994.

36 Ignacio Ellacuría et al v. El Salvador, para 221.

37 International Convention for the Protection of All Persons from Enforced Disappearance, Article 24(2).

38 United Nations General Assembly, Basic Principles and Guidelines on the Right to a Remedy and Reparation for Victims of Gross Violations of International Human 
Rights Law and Serious Violations of International Humanitarian Law (adopted 21 March 2006, A/RES/60/147), hereinafter Basic Principles.

39 T. van Bowen, 'The United Nations Basic Principles and Guidelines on the Right to a Remedy and Reparations for Victims of Gross Violations of International Human Rights Law and Serious Violations of International Law', http://legal. un.org/avl/pdf/ha/ga_60-147/ga_60-147_e.pdf.

40 Basic Principles, Principle 24.

41 The commentary on the Principle to combat impunity suggests that 'massive or systematic violations' reflects current international law (United Nations Commission on Human Rights, Report of the Independent Expert to Update the Set of Principles to Combat Impunity, 18 February 2005, E/CN.4/2005/102, para 20).

42 J. E. Mendez and F. J. Bariff, 'Truth, Right to, International Protection' (January 2011), in R. Wolfrum (ed.), Max Planck Encyclopaedia of Public International Law (online edn).

43 Ibid.

44 See P. Sherwell, 'Haiti Earthquake: Thousands of Bodies Are Dumped in Stench-Filled Mass Graves', Telegraph, 16 January 2010, http://www.telegraph. co.uk/news/worldnews/centralamericaandthecaribbean/haiti/7005477/Haitiearthquake-thousands-of-bodies-are-dumped-in-stench-filled-mass-graves.html.

45 United Nations Security Council, 'Final Report of the United Nations Commission of Experts established pursuant to Security Council Resolution 780 (1992) Annex X Mass graves' (28 December 1994), UN Doc S/1994/674/Add/2 (Vol. V), p. 5-6, para 9.

46 Rome Statute of the International Criminal Court (adopted 17 July 1998, as amended 16 January 2002), UN Doc A/CONF.183/9, Article 7, hereinafter Rome Statute.

47 Ibid., Article 8.

48 Pohl et al., US Military Tribunal in Nuremberg, Judgment, para. 995.

49 Rome Statute., Article 8(2)b(xxi) and 8(2)(c)(ii).

50 International Criminal Court (ICC), Elements of Crimes, 2011, Definition of committing outrages upon personal dignity as a war crime under Article 8(2)(c) (ii), footnote 57.

51 See Krstić, supra note 5.

52 See Karadžić, supra note 5.

53 Case Concerning Application of the Convention on the Prevention and Punishment of the Crime of Genocide (Croatia v. Serbia), Judgment, International Court of Justice (ICJ), 3 February 2015.

54 ICRC, The Missing and their Families'.

55 Ibid., p. 7.

56 ICRC, 'Guiding Principles/Model Law on the Missing', p. 41.

57 Article 21(2).

58 Article 21(3) (a).

59 Article 21(3)(b).

60 Ibid. 
61 Article 22.

62 Article 23.

63 Commentary to article 21, pp. 46 and 48.

64 Commentary to article 22, p. 48.

65 Ibid.

66 Commentary to article 22, p. 48.

67 UN Human Rights Council (UNHRC), 'Progress Report of the Human Rights Council Advisory Committee on Best Practices on the Issue Of Missing Persons', UN Doc. A/HRC/14/42, 22 March 2010.

68 Ibid., para 68.

69 Ibid., para 70.

70 Ibid., para 78.

71 ICMP, 'Investigatory Standards', http://www.icmp.int/the-missing/ approaches-and-standards/investigatory-standards/.

72 UN Educational, Scientific and Cultural Organisation (UNESCO), International Declaration on Human Genetic Data, 16 October 2003 and The Universal Declaration on Bioethics and Human Rights, 19 October 2015.

73 E. González-Cueva, 'Seeking Options for the Right to Truth in Nepal', International Centre for Transitional Justice, briefing paper, November 2012, p. 4.

74 A. Chatterji and others, 'Buried Evidence: Unknown, Unmarked, and Mass Graves in India,' from http://www.kashmirprocess.org/reports/graves/ BuriedEvidenceKashmir.pdf.

75 Law on missing persons of Bosnia and Herzegovina (ICMP unofficial translation).

76 'Declaration on the Role of the State in addressing the issue of persons missing as a consequence of Armed Conflict and Human Rights Abuses', 19 August 2014, Mostar, available at http://www.icmp.int/wp-content/uploads/2014/08/signeddeclaration-2.pdf.

77 Physicians for Human Rights, 'Securing Afghanistan's Past: Human Identification Needs Assessment Gap and Analysis', 2013, https://s3.amazonaws. com/PHR_Reports/afghan-human-id-needs-assessment-April2013.pdf.

78 ICMP worked towards an agreement with the Libyan Ministry for the Affairs of Families of Martyrs and Missing Persons, while PHR provided a Human Identification Needs Assessment and Gap Analysis.

79 Physicians for Human Rights, 'Libyan Human Identification Needs Assessment and Gap Analysis, March 2013', https://s3.amazonaws.com/PHR_Reports/Libyahuman-remains-id-assessmt-report-Mar-2013.pdf.

80 ICMP, 'Resources', http://www.icmp.int/resources/. No other such legislation could be found by the researcher.

81 UN Report on the Protection of Civilians in the Armed Conflict in Iraq.

82 Ministry of Human Rights, Humanitarian Issues Department, 'Law on Protection of Mass graves', Law No 5, 2006, http://www.icmp.int/wp-content/ uploads/2014/08/law-on-protection-of-mass-graves.pdf.

83 Ibid., Article 1(II).

84 Ibid., Article 6(II)(d). 


\section{Melanie Klinkner}

85 Ibid., Article 7.

86 Ibid., Article 16.

87 Ibid., Articles 10-13.

88 UN Report on the Protection of Civilians in the Armed Conflict in Iraq, p. 36.

89 UNHRC, 'Progress Report', para 74.

90 R. Teitel, 'Transitional Justice Genealogy', Harvard Human Rights Journal, 16 (2003), 69-94.

91 P. Seils, 'Towards a Transitional Justice Strategy for Syria', International Centre for Transitional Justice, Briefing paper, September 2013, p. 5.

92 Rosenblatt points out that there may be objections to exhumations: A. Rosenblatt, Digging for the Disappeared: Forensic Science after Atrocity (Stanford, Stanford University Press, 2015).

93 United Nations Security Council, 'The Rule of Law and Transitional Justice in Conflict and Post-Conflict Societies: Report of the Secretary-General', UN Doc. S/2004/616, 23 August 2004, para 8.

94 Ibid.

95 L. Bickford, 'Transitional Justice', in D. Shelton (ed.), The Encyclopaedia of Genocide and Crimes Against Humanity (Macmillian Library Reference, San Diego, 2004).

96 P. Arthur, 'How “Transitions” Reshaped Human Rights: A Conceptual History of Transitional Justice', Human Rights Quarterly, 31 (2009), 321-67, at p. 324.

97 Ibid., p. 326.

98 University of Ulster, Transitional Justice Institute, 'The Belfast Guidelines on Amnesty and Accountability', 2013, https://www.ulster.ac.uk/_data/assets/ pdf_file/0005/57839/TheBelfastGuidelinesFINAL_000.pdf.

99 Meron, The Humanization of International Law, p. 387.

100 ICMP, 'The Missing. An Agenda for the Future', Conference Report, 2013, http:// www.icmp.int/wp-content/uploads/2014/07/conferencereporteng.pdf.

101 Ibid., point 4 on p. 18.

102 Ibid., point 6 on p. 19. 